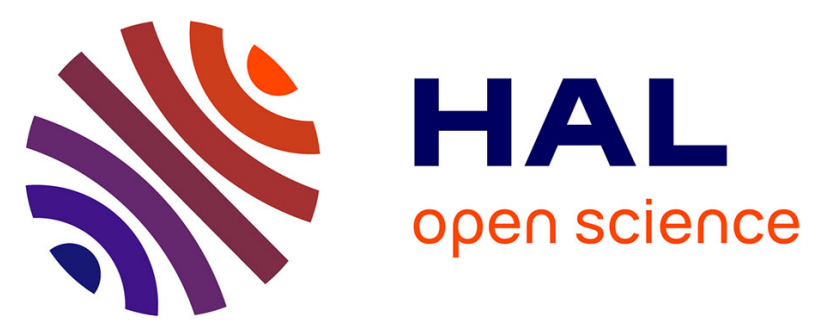

\title{
WHOLE ORBITAL TISSUE CULTURE IDENTIFIES IMATINIB MESYLATE AND ADALIMUMAB AS POTENTIAL THERAPEUTICS FOR GRAVES' OPHTHALMOPATHY
}

Leendert van Steensel, Martin van Hagen, Dion Paridaens, Robert W.A.M. Kuijpers, Willem A. van den Bosch, Hemmo A. Drexhage, Herbert Hooijkaas, Willem A. Dik

\section{- To cite this version:}

Leendert van Steensel, Martin van Hagen, Dion Paridaens, Robert W.A.M. Kuijpers, Willem A. van den Bosch, et al.. WHOLE ORBITAL TISSUE CULTURE IDENTIFIES IMATINIB MESYLATE AND ADALIMUMAB AS POTENTIAL THERAPEUTICS FOR GRAVES' OPHTHALMOPATHY. British Journal of Ophthalmology, 2011, 95 (5), pp.735. 10.1136/bjo.2010.192302 . hal-00614183

\author{
HAL Id: hal-00614183 \\ https://hal.science/hal-00614183
}

Submitted on 10 Aug 2011

HAL is a multi-disciplinary open access archive for the deposit and dissemination of scientific research documents, whether they are published or not. The documents may come from teaching and research institutions in France or abroad, or from public or private research centers.
L'archive ouverte pluridisciplinaire HAL, est destinée au dépôt et à la diffusion de documents scientifiques de niveau recherche, publiés ou non, émanant des établissements d'enseignement et de recherche français ou étrangers, des laboratoires publics ou privés. 
WHOLE ORBITAL TISSUE CULTURE IDENTIFIES IMATINIB MESYLATE AND ADALIMUMAB AS POTENTIAL THERAPEUTICS FOR GRAVES' OPHTHALMOPATHY

Leendert van Steensel, ${ }^{1}$ P. Martin van Hagen, ${ }^{1,2,4}$ Dion Paridaens, ${ }^{4}$ Robert W. A. M. Kuijpers, ${ }^{3}$ Willem A. van den Bosch, ${ }^{4}$ Hemmo A. Drexhage, ${ }^{1}$ Herbert Hooijkaas, ${ }^{1}$ and Willem A. $\operatorname{Dik}^{1}$

Departments of Immunology ${ }^{1}$, Internal Medicine ${ }^{2}$ and Ophthalmology ${ }^{3}$, Erasmus MC, University Medical Center, Rotterdam, The Netherlands.

Rotterdam Eye Hospital ${ }^{4}$, Rotterdam, The Netherlands.

Keywords: Graves' ophthalmopathy, therapy, imatinib mesylate, adalimumab

Word count: 1813

Figures: 2 figures

\author{
Corresponding author: \\ Willem A. Dik, \\ Department of Immunology, Erasmus MC, University Medical Center \\ PO Box 2040 \\ 3000 CA, Rotterdam \\ The Netherlands \\ Phone: $+3110-7043528$ \\ Fax: +3110-7044731 \\ e-mail: w.dik@erasmusmc.nl
}




\section{ABSTRACT}

\section{Background and Aims}

Biologicals and small inhibitory molecules are used to treat inflammatory diseases, but their efficacy varies upon clinical application. Using a whole orbital tissue culture system we tested the potential efficacy of imatinib mesylate (a tyrosine kinase inhibitor that blocks PDGFreceptor, c-Abl and c-Kit activity) and adalimumab (an anti-TNF- $\alpha$ antibody) for the treatment of Graves' ophthalmopathy (GO).

\section{Methods}

Orbital fat tissue from GO patients $(n=10)$ was cultured with or without imatinib mesylate or adalimumab. PDGF-B and TNF- $\alpha$ mRNA expression levels were determined in the primary orbital tissue and IL-6 and hyaluronan were measured in tissue culture supernatants.

\section{Results}

Imatinib mesylate significantly $(\mathrm{p}=0.005)$ reduced IL-6 and hyaluronan production. The inhibition of hyaluronan production correlated positively and significantly $(p<0.05)$ with the PDGF-B mRNA level in the primary tissue. Adalimumab also significantly $(\mathrm{p}=0.005)$ reduced IL- 6 production. The amount of IL- 6 inhibition correlated positively with the TNF- $\alpha$ mRNA level in the primary tissue, but this was not significant.

\section{Conclusions}

Imatinib mesylate can be expected to reduce inflammation and tissue remodeling in GO, while adalimumab can mainly be expected to reduce inflammation. This in vitro tissue culture model may, in future, prove valuable to test novel therapeutics for their presumed effect in GO as well as in other inflammatory diseases. 


\section{INTRODUCTION}

Advances in the understanding of the pathophysiology of inflammatory disorders with regard to cellular involvement as well as the contribution of (soluble) mediators has led to development of biologicals that target cytokines (e.g. adalimumab; a human anti-tumor necrosis factor (TNF)- $\alpha$ antibody), B-cells (e.g. rituximab; an anti-CD20 antibody) or cell-cell interactions (e.g abatacept; a fusion protein that blocks CD80/CD86-induced co-stimulation). Furthermore, small inhibitory molecules directed against specific signaling molecules have been developed, for example imatinib mesylate that targets the tyrosine kinase activity of cABL, c-Kit and the platelet-derived growth factor (PDGF)-receptor.[1-2] The application of these therapeutics has improved the treatment results in various inflammatory disorders, such as rheumatoid arthritis, psoriasis, systemic sclerosis as well as specific uveitis entities.[3-7] Nevertheless, despite the promising results of these therapeutics, a substantial number of patients do not respond, often without a clear explanation, and have to be switched to other therapeutics.

New therapeutics are introduced with a label that describes their application for specific disorders within specific limits. All use outside of this description is off-label and can only be performed if sufficient expectations exist that the agent may indeed prove effective for the disorder. Effective in vitro screening systems may prove helpful to that purpose, especially for rare immune mediated diseases in which the achievement of randomized controlled trials is extremely difficult.[8]

Graves' ophthalmopathy (GO) is an inflammatory fibro-proliferative disease of the orbit, that is characterized by inflammation and excessive orbital fibroblast proliferation and extracellular matrix production (especially hyaluronan), which together cause orbital tissue expansion and proptosis.[9-10] Besides autoantibodies against the thyroid stimulating hormone receptor and the insulin-like growth factor-1 receptor, also cytokines, including 
TNF- $\alpha$ and interleukin (IL)-6, as well as growth factors, such as PDGF, play a role in the pathophysiology of GO.[9, 11-12] In line with the growing importance of biological therapies in clinical practice, several small studies with biologicals have been performed in GO. We demonstrated that TNF- $\alpha$ targeting by etanercept (a TNF-receptor Fc fusion protein) in GO patients resulted in reduction of orbital inflammation.[13] A comparable reduction in inflammation was observed in a GO patient treated with the chimeric anti-TNF- $\alpha$ antibody infliximab.[14] Furthermore, promising results have been obtained with rituximab in GO patients[15].

Recently, we demonstrated an elevated PDGF-B mRNA expression in GO orbital tissue.[11] We showed that PDGF-BB enhanced proliferation as well as cytokine and hyaluronan production by orbital fibroblasts.[11-12] These effects were all efficiently blocked through inhibition of PDGF receptor activity by the tyrosine kinase inhibitors imatinib mesylate and nilotinib.[11-12] Although these data suggest that inhibition of PDGF signaling could be effective in GO, these results were obtained using a single cell (orbital fibroblast) and single mediator (PDGF-BB) culture system, while the orbital pathophysiological process of GO comprises a variety of cell types (e.g. fibroblasts, adipocytes, T cells, B cells, mast cells and macrophages)[9, 16-17] and mediators (e.g. IL-6, TNF- $\alpha$ and TGF- $\left.\beta_{1}\right)[11,13,18]$.

Therefore, to determine the potential efficacy of imatinib mesylate in a physiologically more relevant culture system, we cultured whole orbital tissue from GO patients in the presence or absence of imatinib mesylate and determined the effect on the production of IL-6 and hyaluronan, two important markers in GO. IL-6 is a factor highly expressed in orbital tissue and serum from GO patients[18-20] and is known to recruit and activate B-cells as well as plasma cells.[21] Furthermore, IL-6 enhances the differentiation of orbital fibroblasts into mature adipocytes and the expression of the thyroid stimulating hormone receptor on these adipocytes.[22] Hyaluronan is the most important glycosaminoglycan produced in the orbit 
and its production is strongly enhanced in the orbit of GO patients and thereby contributes markedly to orbital tissue expansion and peri-orbital edema.[9] The same set of experiments was performed with adalimumab in order to examine the effect of specific anti-TNF- $\alpha$ therapy. 


\section{MATERIALS AND METHODS}

\section{Patients}

Orbital fat tissue was obtained from ten patients with GO who underwent orbital decompression surgery for burnt-out ophthalmopathy (Clinical Activity Scores 0/7).[13] All patients were euthyroid and had not received steroid or other immunosuppressive treatment for at least 3 months at the moment of surgery. All tissues were obtained in the Rotterdam Eye Hospital (Rotterdam, the Netherlands) after informed consent had been obtained in accordance with the principles of the Declaration of Helsinki and after approval by the institutional review board at the Erasmus MC, University Medical Center (Rotterdam, the Netherlands).

\section{Orbital tissue culture}

Of each patient, the orbital tissue was cut into 4 equal pieces of which one (further referred to as primary tissue) was immediately snap-frozen for mRNA extraction. The other three pieces were cultured in medium (Dulbecco's Modified Eagle Medium containing 1\% fetal calf serum and antibiotics), medium with imatinib mesylate $(2.5 \mu \mathrm{g} / \mathrm{ml}$, Novartis Pharma, Basel, Switzerland) or medium with adalimumab (10 $\mu \mathrm{g} / \mathrm{ml}$, Abbott, Hoofddorp, the Netherlands) for 48 hours. Hereafter, medium was removed and fresh medium containing the same therapeutic as before was added for another 24 hours. Subsequently, cultured tissues were dried on filtration paper, snap-frozen and weighted. The collected culture supernatants were subjected to IL-6 ELISA (Biosource, London, UK) and hyaluronan ELISA (R\&D Systems, Abingdon, UK).[11-12] 


\section{PDGF-B and TNF- $\alpha$ mRNA expression}

RNA was isolated using Rneasy colums (Qiagen, Hilden, Germany) from snap-frozen primary tissue and reverse transcribed into cDNA. PDGF-B and TNF- $\alpha$ mRNA expression was determined by real-time quantitative PCR (RQ-PCR, 7900 PCR system; Applied Biosystems, Foster City, CA). Transcript levels were normalized to the control gene Abelson.[11]

\section{Statistics}

The effect of imatinib mesylate and adalimumab on IL-6 and hyaluronan levels in culture supernatants were analyzed using the paired Wilcoxon rank sum test. Inhibition indices (calculated as: 1 - the production levels achieved with medication / production levels without medication) were correlated to mRNA expression levels in primary tissue using Spearman's correlation test. p-values $<0.05$ were considered significant. 


\section{RESULTS}

The effect of imatinib mesylate on IL-6 and hyaluronan production by GO orbital tissues

Imatinib mesylate reduced IL-6 and hyaluronan production in all samples (Fig 1A, both $\mathrm{p}=0.005$ ). Similar results were observed when IL-6 and hyaluronan production were corrected for orbital tissue weight (data not shown). The IL-6 inhibition index showed a positive correlation $(r=0.406)$ with the PDGF-B mRNA level in the primary tissue, but this proved not significant (Fig 1B, p=0.244). The hyaluronan inhibition index correlated positively and significantly $(r=0.733, \mathrm{p}=0.02)$ with the PDGF-B mRNA level in the primary tissue (Fig 1B).

\section{The effect of adalimumab on IL-6 and hyaluronan production by GO orbital tissues}

Adalimumab reduced the IL-6 production in all samples (Fig 2A, p=0.005). The hyaluronan production was reduced in 8 of 10 tissues, but this reduction proved not significant (Fig 2A, p=0.06). Similar results were observed when IL-6 and hyaluronan

production were corrected for orbital tissue weight (data not shown). The IL-6 inhibition index showed a positive correlation $(r=0.612)$ with the TNF- $\alpha$ mRNA level in the primary tissue but this proved not significant (Fig $2 \mathrm{~B}, \mathrm{p}=0.06$ ). No positive correlation was observed between the hyaluronan inhibition index and the TNF- $\alpha$ mRNA levels within the primary tissue (Fig 2B, $r=-0.491, \mathrm{p}=0.15)$. 


\section{DISCUSSION}

In this study we use a whole orbital tissue culture system to demonstrate that imatinib mesylate inhibits the production of both IL-6 and hyaluronan, two important components of the pathological process of GO, while adalimumab only reduces IL-6 production.

Previously, we showed that PDGF-BB induced IL-6 and hyaluronan production by orbital fibroblasts in vitro, which was blocked by imatinib mesylate through inhibition of PDGF-receptor activation.[11-12] In our current study, imatinib mesylate reduced IL-6 and hyaluronan production by whole orbital tissues, but a significant positive correlation existed only between the PDGF-B mRNA levels in the primary orbital tissue and the suppression of hyaluronan production. This suggests that hyaluronan production in GO tissue is strongly controlled by PDGF-receptor activation while IL- 6 production involves other stimuli as well (e.g. TNF- $\alpha$ ). However, imatinib mesylate also inhibits the tyrosine kinases c-Abl and cKit.[23] Therefore, we cannot exclude that inhibition of these tyrosine kinases also contributed to the inhibitory effects of imatinib mesylate in our whole tissue cultures. Nevertheless, our previous studies,[11-12] as well as the current study show that imatinib mesylate may potentially reduce inflammation and tissue remodeling in GO. Furthermore, involvement of PDGF-receptor inhibition, at least on orbital fibroblasts but possibly also on other cell types, can be expected herein. Considering this, other tyrosine kinase inhibitors that block PDGF-receptor activation, such as nilotinib and dasatinib, or PDGF neutralizing antibodies can be expected to be effective in the treatment of GO as well.

Adalimumab reduced IL-6 production, but larger series may be needed to demonstrate a correlation between IL- 6 inhibition and the TNF- $\alpha$ mRNA level in the primary tissue. This observation is in accordance with previous studies which demonstrated that TNF- $\alpha$-directed treatment with either etanercept or infliximab reduced peri-ocular inflammation in GO patients.[13-14] The concordance of the observed clinical effects of TNF- $\alpha$-directed treatment 
in GO patients and our in vitro data underscores the strength of the whole orbital tissue culture approach used in this study to screen for potential treatment efficacy.

In our study we used orbital tissue from patients with burnt-out disease, suggesting that imatinib mesylate and adalimumab are effective in this stage of disease. However, imatinib mesylate can be expected to inhibit active disease as well, as target molecules for imatinib mesylate (e.g. PDGF) are equally elevated in active and burnt-out disease.[11] Furthermore, similar levels of TNF- $\alpha$ have been reported in active and burnt-out GO and TNF inhibition by etanercept reduced signs of active GO.[13, 18] Therefore, we expect that TNF- $\alpha$ inhibition by adalimumab will reduce disease activity in active GO as well.

The use of a whole orbital tissue culture has the advantage that it adequately represents the multicellular (e.g. adipocytes, fibroblasts and various immune cells) and multifactorial (e.g. autoantibodies, cytokines, growth factors) pathological process in GO. Therefore, our whole orbital tissue culture is a more suitable approach to test therapeutics than single cell systems. In addition, using specific immune targeted therapies in whole tissue cultures could give more insight into key mediators involved in the pathological process of diseases. Furthermore, it could provide a rationale to start off-label use of novel therapeutics, for instance in rare immune mediated diseases in which achievement of randomized controlled trials is extremely difficult. Clearly, a prerequisite of a whole tissue culture approach is that tissue samples can be obtained relatively easy. Besides GO, this is often the case in idiopathic orbital inflammation and in other inflammatory disorders such as rheumatoid arthritis, psoriasis and systemic sclerosis.

In conclusion, we show that a whole orbital tissue culture system may prove of value to test for possible effects of novel therapeutics in GO. Based on our in vitro results using physiologically relevant concentrations of imatinib mesylate and adalimumab, $[6,24]$ imatinib mesylate can be expected to reduce inflammation as well as tissue remodeling in GO. 
Adalimumab (and other TNF- $\alpha$ neutralizing therapies) may reduce inflammation in GO effectively, but cannot be expected to affect orbital hyaluronan production as effective as imatinib mesylate. 


\section{LICENCE FOR PUBLICATION}

"The Corresponding Author has the right to grant on behalf of all authors and does grant on behalf of all authors, an exclusive licence (or non exclusive for government employees) on a worldwide basis to the BMJ Publishing Group Ltd and its Licensees to permit this article (if accepted) to be published in BJO editions and any other BMJPGL products to exploit all subsidiary rights, as set out in our licence (http://group.bmj.com/products/journals/instructions-for-authors/licence-forms/)." 


\section{FUNDING AND COMPETING INTERESTS}

This work was supported by the 'Stichting Wetenschappelijk Onderzoek Oogziekenhuis' (SWOO 2007-01; LvS), the 'Prof. Dr. Henkes Stichting' and the 'Nederlandse Vereniging van Graves' Patienten (NVGP).

Disclosure summary: PMvH is consultant for Abbott and Novartis Pharma (The Netherlands). All other authors have nothing to disclose. 


\section{REFERENCES}

1. Ong VH, Denton CP. Innovative therapies for systemic sclerosis. Curr Opin Rheumatol, 2010.22(3):264-72.

2. Buch MH. Sequential use of biologic therapy in rheumatoid arthritis. Curr Opin Rheumatol, 2010.22(3):321-9.

3. Kunz M. Current treatment of psoriasis with biologics. Curr Drug Discov Technol, 2009.6(4):231-40.

4. Sfikakis PP, Gorgoulis VG, Katsiari CG, et al. Imatinib for the treatment of refractory, diffuse systemic sclerosis. Rheumatology (Oxford), 2008.47(5):735-7.

5. van Daele PL, Dik WA, Thio HB, et al. Is imatinib mesylate a promising drug in systemic sclerosis? Arthritis Rheum, 2008.58(8):2549-52.

6. Akhmetshina A, Venalis P, Dees C, et al. Treatment with imatinib prevents fibrosis in different preclinical models of systemic sclerosis and induces regression of established fibrosis. Arthritis Rheum, 2009.60(1):219-24.

7. Imrie FR, Dick AD. Biologics in the treatment of uveitis. Curr Opin Ophthalmol, 2007.18(6):481-6.

8. Baeten D, van Hagen PM. Rational therapy and evidence-based medicine: lessons from rare, refractory immune-mediated inflammatory diseases. Ann Rheum Dis, 2010:in press.

9. $\quad$ Bahn RS. Graves' ophthalmopathy. N Engl J Med, 2010.362(8):726-38.

10. van Steensel L, Dik WA. The orbital fibroblast: a key player and target for therapy in graves' ophthalmopathy. Orbit, 2010.29(4):202-6.

11. van Steensel L, Paridaens D, Schrijver B, et al. Imatinib mesylate and AMN107 inhibit PDGF-signaling in orbital fibroblasts: a potential treatment for Graves' ophthalmopathy. Invest Ophthalmol Vis Sci, 2009.50(7):3091-8.

12. van Steensel L, Paridaens D, Dingjan GM, et al. Platelet-derived growth factor-BB: a stimulus for cytokine production by orbital fibroblasts in Graves' ophthalmopathy. Invest Ophthalmol Vis Sci, 2010.51(2):1002-7.

13. Paridaens D, van den Bosch WA, van der Loos TL, et al. The effect of etanercept on Graves' ophthalmopathy: a pilot study. Eye (Lond), 2005.19(12):1286-9.

14. Durrani OM, Reuser TQ, Murray PI. Infliximab: a novel treatment for sightthreatening thyroid associated ophthalmopathy. Orbit, 2005.24(2):117-9.

15. El Fassi D, Nielsen CH, Bonnema SJ, et al. B lymphocyte depletion with the monoclonal antibody rituximab in Graves' disease: a controlled pilot study. J Clin Endocrinol Metab, 2007.92(5):1769-72.

16. Weetman AP, Cohen S, Gatter KC, et al. Immunohistochemical analysis of the retrobulbar tissues in Graves' ophthalmopathy. Clin Exp Immunol, 1989.75(2):222-7.

17. Boschi A, Daumerie C, Spiritus M, et al. Quantification of cells expressing the thyrotropin receptor in extraocular muscles in thyroid associated orbitopathy. $\mathrm{Br} J$ Ophthalmol, 2005.89(6):724-9.

18. Wakelkamp IM, Bakker O, Baldeschi L, et al. TSH-R expression and cytokine profile in orbital tissue of active vs. inactive Graves' ophthalmopathy patients. Clin Endocrinol (Oxf), 2003.58(3):280-7.

19. Molnar I, Balazs C. High circulating IL-6 level in Graves' ophthalmopathy. Autoimmunity, 1997.25(2):91-6.

20. Wakelkamp IM, Gerding MN, Van Der Meer JW, et al. Both Th1- and Th2-derived cytokines in serum are elevated in Graves' ophthalmopathy. Clin Exp Immunol, 2000.121(3):453-7. 
21. Hirano T. Interleukin 6 and its receptor: ten years later. Int Rev Immunol, 1998.16(34):249-84.

22. Jyonouchi SC, Valyasevi RW, Harteneck DA, et al. Interleukin-6 stimulates thyrotropin receptor expression in human orbital preadipocyte fibroblasts from patients with Graves' ophthalmopathy. Thyroid, 2001.11(10):929-34.

23. Druker BJ, Talpaz M, Resta DJ, et al. Efficacy and safety of a specific inhibitor of the BCR-ABL tyrosine kinase in chronic myeloid leukemia. $N$ Engl $\mathrm{J} \mathrm{Med}$, 2001.344(14):1031-7.

24. Karmiris K, Paintaud G, Noman M, et al. Influence of trough serum levels and immunogenicity on long-term outcome of adalimumab therapy in Crohn's disease. Gastroenterology, 2009.137(5):1628-40. 


\section{LEGENDS}

\section{Figure 1}

The effect of imatinib mesylate $(2.5 \mu \mathrm{g} / \mathrm{ml})$ on cultured GO orbital tissues ( $\mathrm{n}=10)$. (A) IL-6 and hyaluronan production is significantly reduced by imatinib mesylate. (B) A positive correlation exists between the IL-6 and hyaluronan inhibition indexes and PDGF-B mRNA expression in the primary tissue, but is only significant for the hyaluronan inhibition index. Each dot represents a single orbital tissue. The effect of imatinib mesylate on IL-6 and hyaluronan production was analyzed using the paired Wilcoxon rank sum test. Correlations were analyzed using Spearman's correlation test. p-values $<0.05$ were considered significant.

\section{Figure 2}

The effect of adalimumab $(10 \mu \mathrm{g} / \mathrm{ml})$ on cultured GO orbital tissues $(\mathrm{n}=10)$. (A) IL-6 production is significantly reduced in tissues by adalimumab, while hyaluronan production is reduced in 8 of 10 orbital tissues. (B) A positive correlation exists between the IL-6 inhibition index and TNF- $\alpha$ mRNA expression in the primary tissue and a negative correlation exists between the hyaluronan inhibition index and TNF- $\alpha$ mRNA expression in the primary tissue, but neither are significant. Each dot represents an individual orbital tissue. The effect of adalimumab on IL-6 and hyaluronan production was analyzed using the paired Wilcoxon rank sum test. Correlations were analyzed using Spearman's correlation test. p-values $<0.05$ were considered significant. 

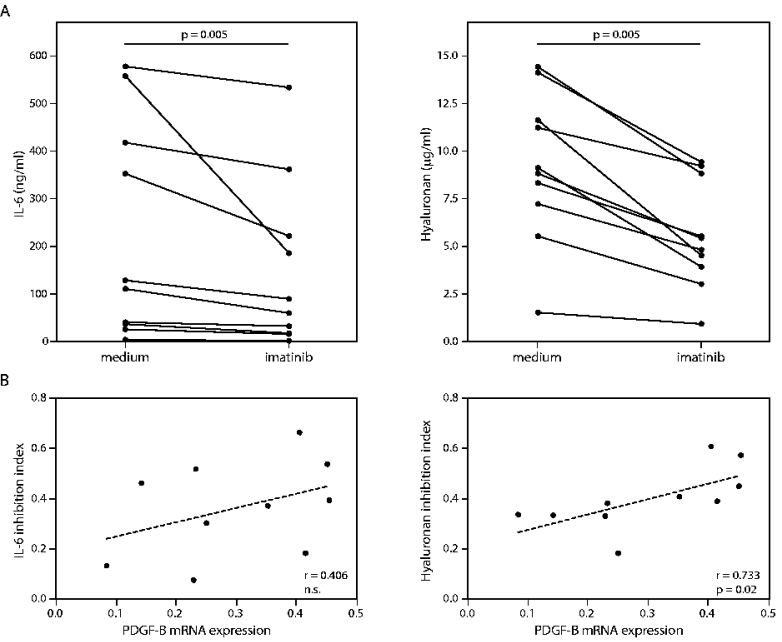

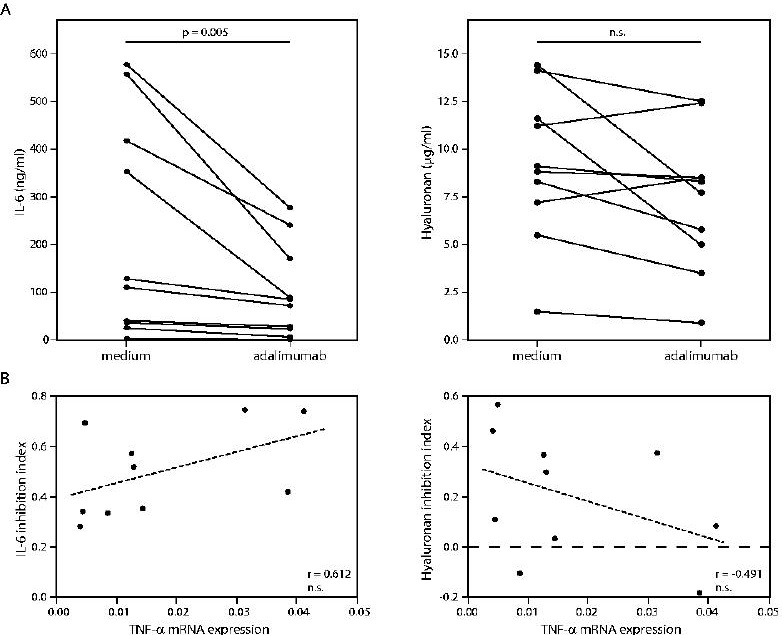